розвитку екологічної освіти, удосконалення фізичної культури, врахування в освіті природних задатків людини тощо).

Принцип природовідповідності у навчанні і вихованні, як надбання педагогічної системи в процесі ії розвитку, обгрунтовувався Я. Коменським, А. Дістервегом, Г. Сковородою, Л. Толстим, М. Максимовичем, В. Сухомлинським.

Відповідно до вказаного принципу у природознавчій (краєзнавчій) освіті реалізуються: екологічна функиія освіти та виховання; освітня функиія культурного удосконалення фізичних якостей та природних задатків людини.

Культура особистості учня набуває рис соцоікультури країни й регіону, і починає здійснювати певний вплив на довкілля. В цьому випадку природознавча (краєзнавча) освіта зокрема виконує продуктивно-результативну функцію, характеристики якої слід розглядати у системі, до складу якої вона входить, потребами, структурою і розвитком якої вони зумовлюються [1, с. 22-23].

Природознавчу (краєзнавчу) освіту слід розглядати через іiі зв'язки з середовищем, по відношенню до якого вона функціонує, тобто через зв'язки з суспільством, людиною, природою, культурою, освітою взагалі. Саме такий підхід дозволяє розглядати природознавчу (краєзнавчу) освіту як закономірно організовану багаторівневу систему, функціонування якої забезпечує досягнення гармонії інтелектуальних й емоційних якостей особистості учнів як здоров'язберігальний чинник.

\title{
Література
}

1. Каган М. С. Системный подход и гуманитарное знание : Избранные статьи / М.С. Каган. Л. : Изд-во Ленин. ун-та,1991. - 384 с. 2. Луговий В. І. Педагогічна освіта в Україні / В. І. Луговий. - К. : МАУП, 1994. - 196 с.

УДК 372.8:004+378.147

М. В. Золочевська, кандидат пед. наук, доцент, К3 «Харківська гуманітарно-педагогічна академія»

\section{МЕТОДИ ТА ПРИЙОМИ РОБОТИ НАД ПОНЯТТЯМИ НА УРОКАХ ІНФОРМАТИКИ}

Золочевська М. В. Методи та прийоми роботи над поняттями на уроках інформатики.

Робота над поняттями є важливим складником дослідницької діяльності, що зумовлює навчання учнів виокремлювати основні поняття предметної області, аналізувати наявні трактування, конструювати поняття на основі істотних ознак. У статті пропонуються методи та прийоми активного навчання роботи з понятійним апаратом на уроках інформатики.

Ключові слова: конструювання понять, методи активного навчання, уроки інформатики.

Золочевская М. В. Методы и приемы работы над понятиями на уроках информатики.

Работа над понятиями является важной составляющей исследовательской деятельности, что обуславливает необходимость обучения выделять основные понятия предметной области, анализировать существующие трактовки, конструировать понятия на основе существенных признаков. В статье предлагаются методы и приемы активного обучения работе с понятийным аппаратом на уроках информатики.

Ключевые слова: конструирование понятий, методы активного обучения, уроки информатики.

Zolochevska M.V. Methods for working teaching how to work with concepts on the lessons of informatics.

Work on concepts is important component of research activity, that's why it's so important for teachers and professors to teach young men to choose main concepts of domain, analyse existing treatments, build concepts based on essential characteristics etc. In the article different methods of teaching how to work with concepts are suggested to the teachers of informatics.

Key words: the building concepts, the methods of active teaching, lessons of informatics.

Навчання через дослідження в контексті виховання обдарованої дитини набуває поширення. Інтенсивно ведуться пошуки шляхів удосконалення процесів навчання та розвитку людини на основі навчання через дослідження, про що свідчать роботи Т. Сгорової, І. Ільницької, М. Кларіна, А. Леонтовича, А. Обухова, О. Подд’якова, 
О. Савенкова, Н. Шумакова та інших. Різні аспекти підготовки вчителів до використання дослідницьких методів у навчанні аналізуються автором у попередніх публікаціях.

Сучасні науковці пропагують активне співробітництво учнів й учителя на різних етапах уроку $[1 ; 3 ; 6]$. Проте у шкільній практиці, особливо під час роботи над поняттями, домінують традиційні технології: учитель передає учням у тому чи тому вигляді готові визначення понять. Водночас, робота $з$ понятійним апаратом, формулювання означень i створення класифікацій є невід'ємним складником дослідницького процесу, оскільки від того, який зміст вкладається в поняття, багато в чому залежить ефективність дослідження, реалізація його цілей та завдань. Саме необхідність застосовувати нові методи і прийоми, щоб залучити всіх учнів до дослідницького процесу, активізувати в них творчий потенціал, інтерес і відповідальність за власну діяльність, визначили актуальність нашого дослідження.

Метою статті є надання методичних рекомендацій учителям щодо застосування методів активного навчання під час роботи над поняттями на уроках інформатики.

Поняття, що становлять зміст предметної галузі інформатики різноманітні й перебувають у постійному розвитку, тому перед учителями (керівниками дослідницької діяльності) постають завдання:

а) допомогти (навчити) виокремлювати основні поняття;

б) забезпечити розгляд понять від простих до складних, організувати осмислення наукових фактів на основі провідних понять, навчитися зв'язувати, узагальнювати, конкретизувати, переосмислювати поняття;

в) визначити міжпредметні зв'язки;

г) проаналізувати, як формується система провідних понять.

Процес формування поняття передбачає такі основні етапи:

a) емпіричне ознайомлення;

б) формулювання означення;

в) застосування в репродуктивній діяльності;

г) застосування у творчій діяльності.

Під поняттям будемо розуміти думку, у якій відображаються загальні, найбільш суттєві властивості предметів чи явищ [5, с. 141]. Формування поняття здійснюється на основі операцій узагальнення й абстрагування: перша операція полягає у виокремленні загального в ряді близьких об'єктів; друга - відволікання від інших ознак. 3 іншого боку, розрізняють родове і видове поняття, які перебувають у відношенні підпорядкування. Розглянемо роботу над поняттями на прикладі поняття «комп'ютер». Суттєвими будемо вважати такі ознаки, кожна з яких є необхідною, а всі разом - достатніми, щоб відрізнити один об'єкт від іншого. Так поняття «комп'ютер» відбиває істотні ознаки всіх існуючих комп'ютерів як універсальних електронних пристроїв для введення, зберігання, опрацювання й передавання даних. Якщо з поняття «комп'ютер» вилучити видові ознаки (універсальність, призначення для зберігання, опрацювання й передавання даних), то перейдемо до родового поняття «електронний пристрій». До електронних пристроїв належать електронні годинники, домофони, термометри, барометри тощо.

Часто традиційні поняття наповнюються новим змістом, і з'являється потреба у їх перегляді, уточненні, іноді - переосмисленні. Так, наприклад, спочатку в англійській мові слово «комп'ютер» означало людину, що виконує арифметичні обчислення із залученням або без залучення механічних пристроїв. Надалі його значення перенесено на машини, однак сучасні комп'ютери виконують безліч завдань, не пов'язаних безпосередньо 3 математикою. Уперше трактування слова «комп’ютер» подано в 1897 році в Оксфордському англійському словнику, укладачі якого сприймали комп'ютер як механічний обчислювальний пристрій. На еволюцію понять такого роду необхідно звертати увагу учнів.

Окрім того, важливо показати, які існують поняття, близькі за змістом, визначити відмінні та спільні риси. Так, при розгляді поняття «комп’ютер» слід звернутися до понять, що 
позначаються абревіатурами «ЕОМ», «ПЕОМ», «ПК». Термін комп’ютер та електронна обчислювальна машина (EOM) уважаються синонімами, але поступово термін «ЕОМ» виходить із лексикону, ним користуються, коли говорять про техніку сорокових - сімдесятих років, особливо радянського виробництва.

Роботу над поняттями слід організовувати так, щоб виконувалося завдання розвитку в учнів навичок мислення високого рівня (уміння аналізувати, синтезувати, оцінювати). Важливо навчити учнів розрізняти зміст поняття (сукупність суттєвих ознак) і обсяг поняття (множину тих об'єктів, на які розповсюджуються поняття). Між змістом поняття і обсягом існує зв'язок: мірою розширення змісту поняття є зменшення його обсягу, i навпаки, мірою збільшення обсягу поняття є зменшення його змісту. У якості прикладу проаналізуємо поняття «комп'ютер» i «ноутбук». За умови звуження поняття «комп'ютер» до поняття «ноутбук» зміст поняття розширюється, тому що до загальних ознак комп'ютера додаються додаткові ознаки: відрізняється невеликими розмірами та вагою, у корпусі містяться типові компоненти (дисплей, клавіатура, сенсорна панель). При цьому обсяг поняття звужується, оскільки кількість ноутбуків менша, ніж загальна кількість комп'ютерів.

Робота над поняттями передбачає ще деякі важливі операції, поміж яких: побудова означення, класифікації тощо. Правильно складена класифікація має задовольняти низку стандартних вимог, з якими потрібно ознайомити учнів. Оптимально це зробити через аналіз типових помилок, які попередньо оформити схематично, наприклад, так, як це пропонують А. Пушкарь і Л. Потрашкова [5, с. 150]. Із понять за допомогою зв'язків між ними вибудовується модель предметної галузі дослідження.

Роботу 3 учнями над поняттям доречно починати 3 актуалізації наявних уявлень. Зіставляючи й обговорюючи уявлення учнів, учитель допомагає сформулювати їх (не обов'язково так, як подається в підручниках). Результатом такої роботи $є$ колективний творчий продукт - спільно сформульоване означення поняття, що записується на дошці. Водночас вчитель пропонує учням ознайомитися з іншими трактуваннями поняття, які наведені, наприклад, авторами різних підручників, посібників, монографій тощо. Різні формулювання залишаються в конспектах учнів як умова їхнього особистісного самовизначення відносно поняття, що досліджується.

Під час конструювання понять можна запропонувати такі прийоми: прийом спільного пошуку, самостійної роботи, порівняння, узагальнення.

Прийом спільного пошуку полягає в тому, що викладач і учні шляхом логічних умовиводів разом приходять до визначення певного поняття.

Приклад 1. Розглянемо приклад роботи 3 поняттям «алгоритм». Процес роботи 3 поняттями проходить у три етапи: учитель пише на дошці термін і пропонує учням назвати по одному-два слова, які пояснюють подане поняття. Учитель фіксує їх на дошці, укладаючи список визначальних слів і словосполучень (наприклад, команди, операції, має результат, приводить до цілі, залежить від виконавця, кроки, детальний, технологія, як виконати, інструкція, складається з вказівок); учитель пропонує виокремити зі списку найбільш істотні й необхідні ознаки, тобто такі, без яких не може існувати поняття (синоніми відкидаються), для нашого приклада це: приводить до цілі, залежить від виконавця, складається з вказівок, кроки; учні синтезують ознаки у визначенні поняття: «алгоритм - упорядкований набір вказівок виконавцю, який приводить цього виконавця до цілі (результату) за скінченну кількість кроків».

Приклад 2. Конструювання поняття «мережа». Спочатку вчитель під час бесіди 3'ясовує, чи зустрічали учні раніше слово «мережа», пропонує навести приклади (транспортна мережа, мережа супермаркетів, телефонна мережа тощо). Для чого об'єднуються об'єкти в мережу? (задля економії ресурсів).

Учитель пише на дошці «Комп’ютерна мережа» і пропонує учням назвати по одномудва слова, які, на їхню думку, пояснили б це поняття. При цьому учитель постійно спонукає до виявлення різних ознак, що властиві об'єкту, ставить запитання: Що об'єднує 
комп’ютерна мережа? (Комп'ютери). А скільки їх може бути? (Різна кількість, але більше одного). Як об'єднуються комп'ютери в мережу? (Через певні спеціальні канали). Чи всі комп'ютери можна включити в мережу, які можна, які «ні»? (Ti, що забезпечені комунікаційним обладнанням і на яких встановлено відповідні програми). Для чого об’єднуються комп'ютери? (Щоб використовувати спільні дані та обладнання).

Відповіді на запитання учні пишуть на дошці. Звичайно, що відповіді можуть відрізнятися від запланованих, потрібно їх уточнити, переформулювати спільними зусиллями, узагальнити. При цьому не слід боятися ознак, які не збігаються із запланованими формулюваннями.

Далі учитель пропонує записати в зошити самостійно визначене поняття «Комп’ютерні мережі» на основі опорних слів на дошці.

Учні здійснюють логічні операції: синтез-аналіз-синтез. Спільний аналіз надає потенційну можливість отримати більше складників для подальшого синтезу. Негативом методу є те, що учитель може втратити контроль над процесом означення поняття, у результаті чого отримане означення може бути неправильним.

Прийом самостійної роботи полягає в тому, що учні вивчають понятійний апарат шляхом пошуку означень понять і вивчення літератури. Учитель рекомендує необхідну літературу, задає напрям пошуку й наприкінці здійснює контроль знань.

Позитивною рисою цього методу є сприяння формуванню в учнів навичок самостійної роботи, відсутність тиску з боку вчителя. Однак учитель не має змоги вплинути на процес формування в учнів уявлень про поняття, внаслідок чого лише підсилюються негативні риси попереднього методу. Крім того, зводиться до мінімуму виховний процес, вплив на особистість учня.

Щоб уникнути впливу негативних чинників, учителю рекомендується на перших етапах самостійної роботи з поняттями надавати учням допомогу, демонструвати спосіб конструювання поняття за допомогою заповнення таблиці. Відтворимо варіант такої таблиці для конструювання поняття «Інформаційне суспільство» (див. табл. 1). Звертаємо увагу, що таблиця 1 демонструє лише один зі способів роботи 3 поняттями за літературними джерелами. Урізноманітнити способи вербалізації роботи над якими дозволяють сучасні програмні засоби, зокрема інструменти побудови схем та діаграм. Учитель інформатики має заохочувати учнів до пошуку різних ознак та різних точок зору. Така робота може бути здійснена над будь-яким 3 понять, уявлення про яке $\epsilon$ важливим для побудови системи знань учнів з інформатики.

Шаблон для конструювання поняття «Інформаційне суспільство»

Таблиия 1

\begin{tabular}{|c|c|c|c|c|c|}
\hline Ознаки & 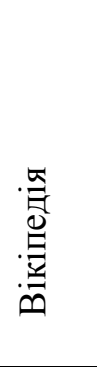 & 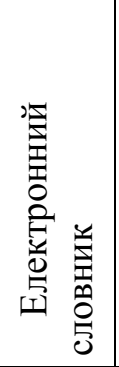 & 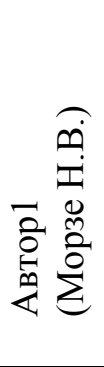 & 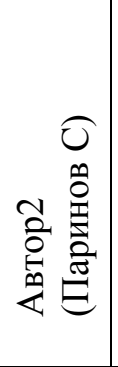 & 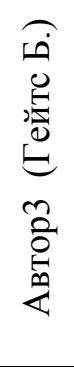 \\
\hline $\begin{array}{l}\text { Збільшення ролі даних і знань у житті суспільства і } \\
\text { окремої людини }\end{array}$ & + & & + & & \\
\hline 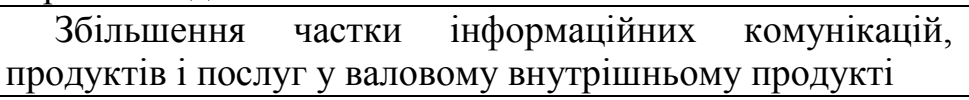 & + & & + & & \\
\hline $\begin{array}{l}\text { Створення глобального інформаційного простору, } \\
\text { який забезпечує.... }\end{array}$ & + & & + & & \\
\hline \begin{tabular}{l}
\multicolumn{3}{c}{ Зростання кількості людей, зайнятих інформаційними } \\
технологіями, комунікаціями \\
iнформаційних продуктів і послуг
\end{tabular} & + & & & & \\
\hline
\end{tabular}




\begin{tabular}{|l|l|l|l|l|l|l|}
\hline $\begin{array}{c}\text { Спрямованість розвитку на виробництво, } \\
\text { опрацювання, зберігання й розповсюдження даних та } \\
\text { відомостей серед членів суспільства }\end{array}$ & & & & & \\
\hline ІНШ ОЗНАКИ: & & & & & & \\
\hline Додати самостійно & & & & & & \\
\hline
\end{tabular}

Прийом порівняння та аналогії полягає в тому, що зміст поняття визначається шляхом порівняння декількох понять. Порівнюються близькі або протилежні за значенням поняття, тобто поняттю надається визначення шляхом протиставлення іншому поняттю (наприклад, ярлик і файл). Операція порівняння дозволяє наочно продемонструвати розходження між декількома поняттями й у такий спосіб уникнути плутанини.

Прийом узагальнення. Побудова попередньої моделі дослідження вимагає умінь подавати відомості у різних формах: текстовій, графічній, табличній, у вигляді макетів, програм тощо. Ці вміння мають дві площини: уміння створити уявний образ і уміння його реалізувати (унаочнити). За допомогою сучасних комп'ютерних технологій дослідник одержує широкий спектр можливостей подавати відомості у зручному вигляді, зберігаючи ресурси, однак вимагають від дослідника високого рівня обізнаності в них. Окрім широко відомих інструментів, що входять до складу додатків пакету Microsoft Office, за допомогою яких створюються організаційні діаграми, електронні таблиці, графіки, малюнки, постійно створюються нові засоби, зокрема такі, як інструменти роботи 3 діаграмами зв'язків, які мають назву «mind map» або, в перекладі, такі назви: «карти розуму», «інтелект-карти», «карти пам'яті», «майнд-мепи», «ментальні карти», «діаграми зв'язків» тощо. Діаграма зв'язків реалізується у вигляді деревоподібної схеми, на якій зображені слова, ідеї, завдання або інші поняття, зв'язані галузями, що відходять від центрального поняття або ідеї. Діаграми зв'язків використовують для візуалізації, структуризації й класифікації ідей, а також як засіб для навчання, організації, розв'язування завдань, прийняття рішень, при написанні статей. На нашу думку, їх достатньо ефективно використовувати для побудови первинної моделі об'єкта та предмета дослідження, виявлення проблем, їх взаємозв'язків.

Такі карти можна створювати вручну, але оволодіння спеціалізованими інформаційнокомунікаційними засобами надасть цьому процесу певної технологічності і наочності.

Отже, робота над поняттями на уроках з будь-якої теми за умови правильної організації методичної роботи вчителя може стати важливою передумовою успішної дослідницької діяльності учнів. При цьому змінюється роль вчителя 3 транслятора «готових знань» на помічника, фасилітатора, який ставить задачу, забезпечує доступ до необхідних учням матеріалів, створює комфортну атмосферу, об'єднує учасників команди, сприяє плідному спілкуванню, спрямовує роботу груп учнів. Для виконання названих функцій вчителю доцільно творчо застосовувати методи та прийоми активного навчання, окреслені в публікації.

\section{Література}

1. Боно Э. Серьезное творческое мышление / Э. Боно [пер. с англ. Д. Я. Онацкая]. - Мн. : 000 «Попурри», 2005. - 416 с. :ил. 2. Золочевська М. В. Методична підготовка майбутніх учителів інформатики до використання дослідницьких методів навчання / М. В. Золочевська, Н. В. Морзе // Інформаційні технології і засоби навчання: електронне наукове фахове видання. - 2010. - № 3(17) - Режим доступу : http://www.ime.edu-ua.net/em17/emg.html. 3. Гін А. О. Прийоми педагогічної техніки: посібник для вчителів / А. О. Гін - Луганськ : СПД Рєзніков В.С., 2007. - 100 с. 4. Ивин А. А. Искусство правильно мыслить / А. А Ивин. - [Изд. 2-е.] - М., Просвещение, 1990. [Электронный pecypc]. - Режим доступа: http://www.geocities.com /geotheism/index.html. 5. Пушкарь А.И. Основы научных исследований и организация научно-исследовательской деятельности: учебное пособие / А. И. Пушкарь, Л. В. Потрашкова - Харьков : ИД «ИНЖЕК», 2008. - 2 изд. - 280 с. 6. Хуторской А. В. Как стать ученым. Занятия по физике со старшеклассниками / А. В. Хуторской, Л. Н. Хуторская, И. С. Маслов - М. : Глобус, 2008. 